\title{
Denizli ili Çivril ilçesinde elma üretimi yapan tarım işletmelerinde üreticilerin tarım sigortası yaptırma tercihleri
}

\author{
Assessment of agricultural insurance preferences of farmers producing apple in Çivril district of Denizli \\ province
}

\author{
Ayşe TEKIN ${ }^{1 \mathscr{O}}$ (D), Bahri KARLI² \\ ${ }^{1}$ Isparta Uygulamalı Bilimler Üniversitesi, Fen Bilimleri Enstitüsü, Tarım Ekonomisi Anabilim Dalı, Isparta, TURKEY. \\ ${ }^{2}$ Isparta Uygulamalı Bilimler Üniversitesi, Ziraat Fakültesi, Tarım Ekonomisi Bölümü, Isparta, TURKEY.
}

MAKALE BILGISI / ARTICLE INFO

\section{Makale tarihçesi / Article history:}

DOI: $10.37908 /$ mkutbd.697737

Geliş tarihi /Received:03.03.2020

Kabul tarihi/Accepted:12.08.2020

\section{Keywords:}

Çivril, apple manufacturers, sociodemographic characteristics, agricultural insurance

\footnotetext{
Corresponding author: Ayşe TEKiN

$\bowtie$ :prof.aysetekin@gmail.com
}

\section{ÖZET / A BSTRACT}

Aims: The aim of this study is to determine the factors that affect the agricultural insurance and non-insurance preferences of the farmers dealing with apple cultivation in Çivril district of Denizli province, Turkey. Methods and Results: In the district, where apple production is intense, insurance applications are also widespread in agriculture. Therefore, the target groups in this study were the farmers insuring their products and the ones non-insuring. A face-to-face survey method was used to interview total of 144 farmers who were, by proportional method, insuring (72) and non-insuring (72) for their apple yield in 2016-2017 growing season. Sociodemographic characteristics of both type of farms were examined. According to the results of the research; $86.81 \%$ of total producers have been aware of agricultural insurance for an average of 5 years. It was determined that $75.69 \%$ of the producers provided information on agricultural insurance from the District Directorate of Agriculture and Forestry, insurance companies, television and internet sources. It was found that $69.44 \%$ of the farmers/farms were positively affected by the government's insurance premium support application whereas the remaining $30.56 \%$ of the producers are not affected.

Conclusions: The average of the apple planted areas of the farms that had insurance for the 2017 production season was 35 da. In addition, it was found that the producers who insured had paid 6762 TL premium fee on average. The fact that the average age of the producers having insurance was small, their education levels were high and larger acreages of their farms have a positive effect on their insurance preferences. On the other hand, the non-insured producers, factors such as being elder, having smaller acreage with fractal structure, being less educated were critical for their insurance preferences.

Significance and Impact of the Study: Risks threatening apple production in Çivril district of Denizli province and the attitudes of the producers towards these risks, the socio-demographic characteristics of the producers and the preferences of having / not having insurance.

Atıf / Citation: Tekin A, Karlı B (2021) Assessment of agricultural insurance preferences of farmers producing apple in Çivril district of Denizli province. MKU. Tar. Bil. Derg. 26(1) : 8-19. DOI: 10.37908/mkutbd.697737

\section{GiRiş}

İnsanlığın başlangııından bugüne kadar sosyal ve ekonomik yaşamın vazgeçilmezi olan tarım, sanayi ve hizmet sektörlerine oranla politik, ekonomik ve doğal koşullardan en fazla etkilenen sektördür. Tarım, farklı 
dönemlerde çeşitli üretim biçimleri ile şekillendirilmiş ve risklere karşı farklı stratejiler geliştirilmiştir. Çünkü tarım sektörü kırsal nüfusu kalkındıran, milli ekonomiye katkı sağlayan, sanayiye hammadde temin eden ve ihracat gelirlerinin arttırılması açısından her ülke için önemli bir sektör haline gelmiştir (Keskinkılıç, 2013). Dolayısıyla, tarımsal üretim hem doğal hem ekonomik risk ve belirsizliklerden en fazla etkilenmektedir. Tarımda sık sık risklerle karşı karşıya kalan üretim çeşidi ise bitkisel üretimdir. Don, dolu, rüzgâr, sel, kuraklık ve yangın gibi doğal koşulların bitkisel üretimi olumsuz etkilemesi o bölgede kıtlığa, üreticinin borçlanmasına, gelecek dönemde verimsiz ve kalitesiz hasat döneminin meydana gelmesine neden olmaktadır. Çünkü bitkisel üretimde, ürünlerin sigortalanması ile risk ve belirsizliklere karşı mücadele etme üreticilerin tutum ve davranışları; üretim faaliyetinin şekli (ürünler), üretim faaliyetine yapılan yatırımın ölçüsü, bilgi düzeyi ve yeniliklere bakış açısı, gelir düzeyi, üretimde sürdürülebilirliğin sağlanması ve geleceğe dair beklentileri açısından yakından ilgilidir. Bunun için geleceğe yönelik tarımda en etkili risk yönetim aracı tarım sigortasıdır (Çetin, 2007). Türkiye nüfusunun $\% 23$ ü tarım ile geçimini sağlamaktadır ve dünyada da bazı tarımsal ürünlerde önde gelen ülkelerden olmuştur. Bu bakımdan Türkiye tarım sigortası açısından büyük bir potansiyele sahiptir (Sevim, 2010). Türkiye'de tarımsal sigortacılık kavramı ile ilgili kanunen ilk hükümlere 1926 yılında Türk Ticaret Kanunu'nda rastlanmaktadır. Günümüzde ise 5363 sayılı Tarım Sigortaları Kanunu, Türkiye'de 14.06.2005 tarihinde kabul edilmiştir (Uralcan, 2005). Türkiye'nin Avrupa Birliği'ne üyelik sürecine girdiği dönem içerisinde, gelişmiş ülkelerin tarım sigortası uygulamaları da incelenmiş, İspanya'da uygulanmakta olan ve devletin \%50 mali destek sağladığı modelden esinlenilerek alt yapısı oluşturulmuştur. Kanun gereğince bir havuz sistemi oluşturulmuş ve eşit sermayelerle bir araya gelen sigorta şirketlerince havuzun yürütme işlerini halledecek işletici şirket olan TARSiM kurulmuştur (Yavuz, 2010).

2018 yılında TARSiM' de devlet destekli tarım sigortalarında toplam poliçe sayısı yıllık \%9.9'luk bir artış ile 1.756.428 adet olarak gerçekleşmiştir. Toplam prim tutarı \%25.9 artışla 2.050.635.088 TL olurken, toplam devlet destek prim tutarı da \%24 artışla 1.072.036.127 TL olarak gerçekleşmiştir. Sigorta ettirilen alan (sera dâhil) 2018 yılında \%5.9 artış göstererek 24.742.018 da olmuştur. Toplam ödenen hasar bedeli branşlara göre incelendiğinde ilk sırayı 723.949.578 TL bedel ile bitkisel ürünler sigortası almaktadır. Toplam ödenen hasar bedeli incelendiğinde ise $468.780 .791 \mathrm{TL}$ bedel ile dolu olayı ilk sırayı almaktadır (TÜiK, 2019). Dünyada ve Türkiye'de; bitkisel üretimde risk ve belirsizlikleri irdelenmesi, tarım işletmelerinde risk ve belirsizlikleri giderecek tarım sigortası uygulamalarının belirlenmesi ve üreticilerin tarım sigortasına karşı tutum ve davranışlarının ortaya konulması hususunda işletme düzeyinde ve genel değerlendirme olmak üzere çok sayıda araştırma yapılmıştır. Bu araştırmalardan bazıları; Ceyhan ve ark. (1996), Akdemir ve ark. (2001), Binici ve ark. (2003), Akçaöz ve ark. (2006), Çukur ve ark. (2008), Pezikoğlu ve ark. (2012), Hasdemir ve ark. (2014), Sayın ve ark. (2014), Ghazanfar et al. (2015), Terin ve Aksoy (2015), Arshad et al. (2015), Farzaneh et al. (2017), Tekin et al. (2017), Kızıloğlu (2017) ve íkikat Tümer ve ark. (2019)'ın çalışmaları sayılabilir.

Bu çalışmada, Denizli ili Çivril ilçesinde elma üretimini tehdit eden riskler ve bu risklere karşı üreticilerin tutumları, üreticilerin sosyo-demografik özellikleri ve sigorta yaptırma/yaptırmama tercihleri irdelenmiştir.

\section{MATERYAL ve YÖNTEM}

Çivril ilçesi elma üretiminin yoğun olarak yapıldığı bir bölgedir. Bunun yanında, üreticilerin elma üretiminde tarım sigortası yaptırma oranı artış eğilimindedir. Bu nedenle çalışma alanı olarak bu bölge seçilmiştir. Çalışmanın ana materyali Denizli ili Çivril ilçesinde Doğluköy, Emirhisar, Işıklı, Sundurlu, Yalınlı ve Yeşilyaka 'da faaliyet gösteren toplam 144 elma üreticisi ile anket yoluyla görüşülerek elde edilmiştir. Ayrıca konu ile ilgili ikincil kaynaklar incelenmiştir. Yapılan anket çalışmasına ait örneklem sayısının belirlenmesinde oransal yöntem kullanılmıştır. Sigorta yaptıran 72 ve sigorta yaptırmayan 72 olmak üzer toplam 144 üretici ile çalışma yapılımıştır. Verilerin değerlendirilmesinde Khi-kare analizi yöntemi ve ortalamalar kullanılmıştır.

\section{ARAŞTIRMA ve BULGULAR}

\section{incelenen elma işletmelerine ait genel bilgiler}

Yapılan çalışmada 144 üreticinin yaş gruplarına göre dağılımından elde edilen verilere göre \%44.44'ü 45 yaşın altında ve $\% 55.56$ 'sının 45 yaşın üstünde olduğu tespit edilmiştir. Üreticilerin geleceklerine dair \%47.92 ile çoğunluğunun SGK ile sosyal güvenceye sahip olduğu anlaşılmaktadır. İkinci sırada ise \%42.36 ile BAĞ-KUR gelmektedir. Sigorta yaptıranlarda ortalama gelir 58861 TL, sigorta yaptırmayanlarda ise 49305 TL'dir. Sigorta yaptıran üreticilerin gelir düzeylerinin daha yüksek olduğu ve tarım dışı geliri olan üretici sayısının fazla olduğu anlaşılmıştır. Üretici gruplarının sosyodemografik özelliklerinin sigorta yaptırma/yaptırmama tercihlerini etkilediği gözlenmiştir. 
Ürün sigortası yaptıran üreticilerin \%54.17'sinin 45 ve altı yaş grubuna ait olduğu belirlenmiştir. Sigorta yaptırmayan üreticilerde ise en fazla sigorta yaptırmayan yaş grubu \% 65.28 ile 45 yaş ve üstü olmuştur. Yapılan Khi-kare analizine göre işletme yaş grupları itibariyle tarımsal sigorta yaptıran ve yaptırmayan üreticiler arasında istatistiksel açıdan fark bulunmuştur. Işletmelerde yaş ortalaması küçüldükçe üreticilerin sigorta yaptırma tercihinin olumlu olduğu belirlenmiştir. Genç üreticilerin yenilikleri ve teknolojiyi kendi lehlerine değerlendirmeye daha meraklı oldukları gözlenmiştir (Çizelge 1).

Çizelge 1. İşletme yaş grupları

Table 1. Enterprises age groups

\begin{tabular}{lccccccc}
\hline \multirow{2}{*}{ Yaş } & \multicolumn{3}{c}{ Sigorta durumu } & \multicolumn{3}{c}{ Khi-Kare } \\
\cline { 2 - 8 } & $\begin{array}{c}\text { Yaptırıyor } \\
(\mathrm{N})\end{array}$ & $\%$ & $\begin{array}{c}\text { Yaptırmıyor } \\
(\mathrm{N})\end{array}$ & $\%$ & Değeri & Sd & $\mathrm{p}^{*}$ \\
\hline 45 ve altı & 39 & 54.17 & 25 & 34.72 & 5.512 & 1 & 0.019 \\
46 ve üstü & 33 & 45.83 & 47 & 65.28 & & \\
\hline Toplam & 72 & 100.00 & 72 & 100.00 & & \\
\hline
\end{tabular}

*Khi-kare testine göre gruplar arasındaki fark $p<0.05$ için anlamlıdır

Her dönem yeni teknoloji fırsatları tarımı bir adım daha ileriye taşımış, zaman ve masraflardan üreticilerin tasarruf etmelerini sağlamıştır. Nitekim üreticilerin eğitim düzeyi yüksek olanlar fırsatları kovalarken, düşük olanlar geleneksel yöntemlerle ilerlemeyi tercih etmiştir. Araştırma kapsamında ise tarım sigortası yaptıran üreticilerin \%47.22'sinin lise mezunu ve üstü eğitim düzeyine sahip olduğu, tarım sigortası yaptırmayan üreticilerin ise \%30.56'sının ilköğretim mezunu olduğu saptanmıştır. Yapılan Khi-kare analizine göre işletme eğitim durumlarına göre tarımsal sigorta yaptıran ve yaptırmayan üreticiler arasında istatistiksel açıdan fark bulunmuştur. Sigorta yaptıran üreticilerin eğitim düzeylerinin daha yüksek olduğu ve tarım sigortasına yönelik tercihlerinin daha olumlu olduğu belirlenmiştir (Çizelge 2).

Çizelge 2. İşletmelerin eğitim düzeyleri

Table 2. Education levels of enterprises

Sigorta durumu

Khi-Kare

Eğitim

\begin{tabular}{lccccccc}
\cline { 2 - 6 } & $\begin{array}{c}\text { Yaptırıyor } \\
(\mathrm{N})\end{array}$ & $\%$ & $\begin{array}{c}\text { Yaptırmıyor } \\
(\mathrm{N})\end{array}$ & $\%$ & Değeri & Sd & $\mathrm{p}^{*}$ \\
\hline Okuma-yazma yok & 0 & 0.00 & 2 & 2.78 & & & \\
Okur-yazar & 4 & 5.56 & 14 & 19.44 & & & \\
Ilköğretim & 20 & 27.78 & 22 & 30.56 & 12.707 & 4 & 0.013 \\
Ortaöğretim & 14 & 19.44 & 16 & 22.22 & & & \\
Lise ve üstü & 34 & 47.22 & 18 & 25.00 & & & \\
\hline Toplam & 72 & 100.00 & 72 & 100.00 & & \\
\hline
\end{tabular}

*Khi-kare testine göre gruplar arasındaki fark $p<0.05$ için anlamlıdır.

Sigorta yaptıran işletmelerde ortalama gelir $58861 \mathrm{TL}$, sigorta yaptırmayan işletmelerde ise 49305 TL'dir. Yapılan Khi-kare analizine göre sigorta yaptıran ve yaptırmayan işletmelerin gelirleri arasında istatistiksel olarak fark bulunmuştur. İşletme gruplarında sigorta yaptıran üreticilerin, sigorta yaptırmayan üreticilere oranla gelir düzeyinin daha iyi olduğu saptanmıştır (Çizelge 3). 
Çizelge 3. İşletmelerin gelir varlığı durumları

Table 3. Income status of enterprises

\begin{tabular}{lccccccc}
\hline \multirow{2}{*}{ işletme gelir (TL) } & \multicolumn{9}{c}{ Sigorta durumu } \\
\cline { 2 - 7 } & $\begin{array}{c}\text { Yaptırıyor } \\
\text { (N) }\end{array}$ & $\%$ & $\begin{array}{c}\text { Yaptırmıor } \\
(\mathrm{N})\end{array}$ & $\%$ & Değeri & Sd & $\mathrm{p}^{*}$ \\
\hline $1000-30000$ & 14 & 19.44 & 22 & 30.56 & & & \\
$31000-60000$ & 37 & 51.39 & 37 & 51.39 & 3.66 & 2 & 0.16 \\
$61000-+$ & 21 & 29.17 & 13 & 18.06 & & & \\
\hline Toplam & 72 & 100.00 & 72 & 100.00 & & \\
\hline
\end{tabular}

*Khi-kare testine göre gruplar arasındaki fark $p<0.05$ için anlamlıdır.

Türkiye'nin farklı bölgelerinde ve farklı yıllarda yapılan çalışmalarda da, tarım sigortası yaptırma karar verme sürecinde ve sigorta yaptırma arzusunda gelirin pozitif etki ettiği (Yavuz, 2010; ikikat Tümer, 2011; Kiracı ve ark., 2014; Kızıloğlu, 2017; Kabaoğlu ve Birinci, 2019) ortaya konulmuştur.

Üreticiler, işletmelerinin ve tarımsal üretimin devamlılı̆ıını sağlayabilmek için üretim dönemi boyunca intiyaç duyacakları girdi ve finansman desteğini sağlayabilmek için işletme dışı kaynaklara başvurmaktadırlar. Türkiye'de bu kaynakların başında

öncelikle T.C. Ziraat Bankası ve Tarım Kredi Kooperatifleri gelmektedir (Boz, 1993).

Tarım sigortası yaptıran işletmelerin \%58.33'ünün tarımsal kredi kullandığı belirlenmiştir. Tarım sigortası yaptırmayan işletmelerin ise sadece \% 29.17'sinin tarım kredisi kullandığı tespit edilmiştir. Khi-kare analizi sonuçlarına göre ise her iki üretici grubu arasında kredi kullanımı ile ilgili anlamlı bir fark bulunmuştur. Sigorta yaptıran üreticilerin girdi ve finansman desteği için daha fazla kredi kullandıkları saptanmıştır (Çizelge 4).

Çizelge 4. İşletmelerin kredi kullanım durumları

Table 4. Credit usage situations of enterprises

\begin{tabular}{lccccccc}
\hline & \multicolumn{3}{c}{ Sigorta durumu } & \multicolumn{2}{c}{ Khi-Kare } \\
\cline { 2 - 7 } Kredi kullanımı & $\begin{array}{c}\text { Yaptırıyor } \\
(\mathrm{N})\end{array}$ & $\%$ & $\begin{array}{c}\text { Yaptırmıyor } \\
(\mathrm{N})\end{array}$ & $\%$ & Değeri & Sd & $\mathrm{p}^{*}$ \\
\hline Kullanıyorum & 42 & 58.33 & 21 & 29.17 & \multirow{2}{*}{0.444} & 1 & 0.000 \\
Kullanmıyorum & 30 & 41.67 & 51 & 70.83 & & \\
\hline Toplam & 72 & 100.00 & 72 & 100.00 & & \\
\hline
\end{tabular}

*Khi-kare testine göre gruplar arasındaki fark $p<0.05$ için anlamlıdır.

İşletmelerin genelinin tarım dışı gelir faaliyetlerine bakıldığı zaman \%52.78'nin farklı mesleklerde ikinci işleri vardır. Sigorta yaptıran üreticilerin \%56.94'ünün tarım dışı ek gelire sahip olduğu belirlenmiştir. Tarım sigortası yaptıran üreticilerin genellikle ek gelir elde ettikleri meslekler; esnaf, balıkçılık, işçi, memur, operatör, marangoz, tamirci, tüccar, pazarlamacı ve laborant olduğu belirlenmiştir. Sigorta yaptırmayan üreticilerin ise $\% 48.61^{\prime} i$ tarım dışı mesleklerden gelir elde etmektedir. Tarım sigortası yaptırmayan üreticilerin genellikle ek gelir elde ettikleri meslekler ise; inşaat, balıkçılık, işçi, operatör, tamirci ve pazarlamacı olduğu belirlenmiştir. Khi-kare analiz sonuçlarına göre ise istatistiksel olarak iki grup arasında fark bulunmamıştır.
Ancak tarım dışı gelir oranlarının sigorta yaptıran üreticilerde daha yüksek olduğu belirlenmiştir (Çizelge $5)$. 
Çizelge 5. İsletmelerin tarım dışı gelir varlığı

Table 5. Non-agricultural income status of enterprises

\begin{tabular}{lccccccc}
\hline \multirow{2}{*}{ Üretici cevapları } & \multicolumn{3}{c}{ Sigorta durumu } & \multicolumn{2}{c}{ Khi-Kare } \\
\cline { 2 - 8 } & $\begin{array}{c}\text { Yaptırıyor } \\
(\mathrm{N})\end{array}$ & $\%$ & $\begin{array}{c}\text { Yaptırmıyor } \\
\text { (N) }\end{array}$ & $\%$ & Değeri & Sd & \multirow{2}{*}{$\mathrm{p}^{*}$} \\
\hline Tarım dışı gelirim var & 41 & 56.94 & 35 & 48.61 & \multirow{2}{*}{1.003} & \multirow{2}{*}{1} & \multirow{2}{*}{0.317} \\
Tarım dışı gelirim yok & 31 & 43.06 & 37 & 51.39 & & \\
\hline Toplam & 72 & 100.00 & 72 & 100.00 & & \\
\hline
\end{tabular}

*Khi-kare testine göre gruplar arasındaki fark $p>0.05$ için anlamsızdır.

İşletmelerin arazi genişlik grupları ile ürün sigortası yaptırma/yaptırmama tercih durumu arasında Khi-kare analizine göre anlamlı bir fark ortaya çıkmıştır. Üretici grupları karşılaştırıldığında, 20 da üstünde araziye sahip olan üreticilerin sigorta yaptırdığı ve 20 da altında araziye sahip olan üreticilerin ise sigorta yaptırmadıkları sonucuna ulaşılmıştır. Sahip olunan işletmenin büyüklüğünün artması ürün sigortası yaptırma talebini de arttırmakta olduğu saptanmıştır. Dolayısıyla geniş araziye sahip olan üreticilerin aile ekonomilerini, gelirlerini ve üretimde sürekliliği garanti altına almak için sigorta yaptırdıkları anlaşılmıştır (Çizelge 6).

Çizelge 6. işletme arazi genişliği grupları

Table 6. Enterprises land width groups

\begin{tabular}{lccccccc}
\hline & \multicolumn{3}{c}{ Sigorta durumu } & \multicolumn{3}{c}{ Khi-Kare } \\
\cline { 2 - 7 } isletme arazi $(\mathrm{da})$ & $\begin{array}{c}\text { Yaptırıyor } \\
(\mathrm{N})\end{array}$ & $\%$ & $\begin{array}{c}\text { Yaptırmıyor } \\
(\mathrm{N})\end{array}$ & $\%$ & Değeri & Sd & $p^{*}$ \\
\hline $1-20$ & 7 & 9.72 & 23 & 31.94 & & \\
$21-40$ & 20 & 27.78 & 26 & 36.11 & 16.434 & 2 & 0.000 \\
$41-+$ & 45 & 62.5 & 23 & 31.94 & & & \\
\hline Toplam & 72 & 100.00 & 72 & 100.00 & & \\
\hline
\end{tabular}

*Khi-kare testine göre gruplar arasındaki fark $p<0.05$ için anlamlıdır.

İşletmelere ait genel arazi özelliklerine göre görüşülen üreticilerin toplam işletme arazileri ortalama 58354.17 da olup, arazinin \%4.31'i işlenmeyen araziden oluşmaktadır. Üreticilerin sahip olduğu toplam işletme arazilerinin $\% 52.09$ 'u elma yetiştiriciliği, $\% 47.91^{\prime} i$ ise diğer ürünlerin (şeftali, kiraz, ayçiçeği, haşhaş, yonca, mısır, arpa, buğday) yetiştirilmesi için kullanıldığı belirlenmiştir. Ayrıca üreticilerin toplam işletme arazisi, mülk arazi ve elma yetiştirilen arazi ortalamaları sigorta yaptıran işletmelerde yüksek olduğu saptanmıştır. Sigorta yaptıran üreticilerin daha fazla tarım arazisine sahip olduğu ve arazilerinin yarıdan fazlasında sulu tarım yaptıkları gözlenmiştir. Sigorta yaptırmayan üreticilerin daha az mülk araziye sahip oldukları belirlenmiştir. Ortak arazi kullanımı ve kiralık arazi kullanımının ortalamalarının yine sigorta yaptıran üreticilerde, sigorta yaptırmayan üreticilere göre daha yüksek olduğu anlaşılmıştır.

Elma yetiştirilen arazi büyüklüğü ile ürün sigortası yaptırma oranı arasında anlamlı bir ilişki bulunmaktadır. Yapılan Khi-kare analizine göre elma yetiştirilen işletme alanı ile tarımsal sigorta yaptıran ve yaptırmayan üreticiler arasında istatistiksel açıdan fark bulunmuştur. Daha fazla elma ağacına sahip olan üreticiler, gelirlerini ve yaptıkları masrafları göz önünde bulundurarak zarar etmek istememektedirler. Bunun içinde ürün sigortasına olan talep ağaç sayısı arttıkça daha fazla olmaktadır (Çizelge 7). 
Çizelge 7. Elma yetiştirilen işletme arazi genişliği grupları

Table 7. Apple growing enterprises' land size groups

\begin{tabular}{lccccccc}
\hline \multirow{2}{*}{$\begin{array}{l}\text { Elma işletme arazisi } \\
\text { (da) }\end{array}$} & $\begin{array}{c}\text { Yaptırıyor } \\
\text { (N) }\end{array}$ & $\%$ & $\begin{array}{c}\text { Yaptırmı } \\
\text { (N) }\end{array}$ & $\%$ & Değeri & Sd & $p^{*}$ \\
\hline $1-20$ & 31 & 43.06 & 53 & 73.61 & & 0.000 \\
$21-40$ & 18 & 25.00 & 15 & 20.83 & 19.405 & 2 & \\
$41-+$ & 23 & 31.94 & 4 & 5.56 & & & \\
\hline Toplam & 72 & 100.00 & 72 & 100.00 & & \\
\hline
\end{tabular}

*Khi-kare testine göre gruplar arasındaki fark $p<0.05$ için anlamlıdır.

\section{incelenen elma işletmelerine hayvan ve alet- makine} varlığı

Denizli ili Çivril ilçesindeki araştırma yapılan köylerde hayvancılık sektörüne göre bitkisel üretim sektörü daha yoğun olarak yapılmaktadır.

Çizelge 8'de Tarım sigortası yaptıran üreticilerin sadece $\% 43.06$ 'sının, tarım sigortası yaptırmayan üreticilerin ise Çizelge 8. İşletmelerin büyükbaş hayvan varlığı

Table 8. Cattle existence of enterprises

\begin{tabular}{lccccccc}
\hline \multirow{3}{*}{ Bb. hayvan varlığı } & \multicolumn{3}{c}{ Sigorta durumu } & \multicolumn{3}{c}{ Khi-Kare } \\
\cline { 2 - 8 } & $\begin{array}{c}\text { Yaptırıyor } \\
(\mathrm{N})\end{array}$ & $\%$ & $\begin{array}{c}\text { Yaptırmıyor } \\
(\mathrm{N})\end{array}$ & $\%$ & Değeri & Sd & $\mathrm{p}^{*}$ \\
\hline Yok & 41 & 56.94 & 49 & 68.06 & 1.896 & 1 & 0.168 \\
Var & 31 & 43.06 & 23 & 31.94 & & \\
\hline Toplam & 72 & 100.00 & 72 & 100.00 & & & \multirow{2}{*}{} \\
\hline
\end{tabular}

*Khi-kare testine göre gruplar arasındaki fark $p>0.05$ için anlamsızdır.

Çizelge 9'da ise üreticilerin sahip oldukları küçükbaş hayvan varlıkları incelenmiştir. Buna göre tarım sigortası yaptıran üreticilerde \%83.33'nün küçükbaş hayvanı bulunmazken, bu üreticilerden \%16.67'sinin küçükbaş hayvanı olduğu belirlenmiştir. Tarım sigortası \%31.94'nün büyükbaş hayvan sahibi olduğu saptanmıştır. Yapılan Khi-kare analizine göre sigorta yaptıran ve yaptırmayan üreticiler arasında istatistiksel açıdan fark bulunmamıştır. Sigorta yaptıran üreticilerin daha fazla büyükbaş hayvan sahibi olduğu belirlenmiştir.

Çizelge 9. işletmelerin küçükbaş hayvan varlığı

Table 9. Sheep and goat existence of enterprises

\begin{tabular}{|c|c|c|c|c|c|c|c|}
\hline \multirow[b]{2}{*}{ Kb. hayvan varlığı } & \multicolumn{3}{|c|}{ Sigorta durumu } & \multicolumn{4}{|c|}{ Khi-Kare } \\
\hline & $\begin{array}{c}\text { Yaptırıyor } \\
\text { (N) }\end{array}$ & $\%$ & $\begin{array}{l}\text { Yaptırmıyor } \\
\text { (N) }\end{array}$ & $\%$ & Değeri & $\mathrm{Sd}$ & $\mathrm{p}^{*}$ \\
\hline Yok & 60 & 83.33 & 58 & 80.56 & \multirow{2}{*}{.188} & \multirow{2}{*}{1} & \multirow{2}{*}{0.665} \\
\hline Var & 12 & 16.67 & 14 & 19.44 & & & \\
\hline Toplam & 72 & 100.00 & 72 & 100.00 & & & \\
\hline
\end{tabular}

*Khi-kare testine göre gruplar arasındaki fark $p>0.05$ için anlamsızdır.

Tarım alet ve makineleri sayısının artması modern tarım tekniklerinin gelişmesinin bir sonucudur. Bunun yanı sıra, traktörün çiftçiler arasında sosyal farklılaşma aracı yaptırmayan üreticilerin ise \%19.44'ünün küçükbaş hayvan sahibi olduğu görülmektedir. Yapılan Khi-kare analizine göre sigorta yaptıran ve yaptırmayan üreticiler arasında istatistiksel açıdan fark bulunmamıştır. 
Araştırmada elde edilen ekipman bilgileri incelendiğinde yapılan Khi-kare analizine göre sigorta yaptıran ve yaptırmayan üreticiler arasında istatistiksel açıdan fark bulunmamıştır. Tarım sigortası yaptıran üreticilerin \%62.50'sinin alet-ekipman makinelerinin (traktör, pulluk, çapa makinası, pülverizatör, gübre dağıtım makinası vb.) hepsine sahip olduğu belirlenmiştir. Sigorta yaptırmayan üreticilerin ise \%54.17'sinin hepsine sahip olduğu belirlenmiştir (Çizelge 10).

Çizelge 10. işletmelerin alet-ekipman ve traktör varlığı

Table 10. The presence of tools-equipment and tractors of enterprises

\begin{tabular}{|c|c|c|c|c|c|c|c|}
\hline \multirow[b]{2}{*}{ Ekipman varlığı } & \multicolumn{3}{|c|}{ Sigorta durumu } & \multicolumn{4}{|c|}{ Khi-Kare } \\
\hline & $\begin{array}{c}\text { Yaptırıyor } \\
\text { (N) }\end{array}$ & $\%$ & $\begin{array}{l}\text { Yaptırmıyor } \\
\text { (N) }\end{array}$ & $\%$ & Değeri & Sd & $p^{*}$ \\
\hline Traktör & 27 & 37.50 & 33 & 45.83 & 1070 & 1 & 210 \\
\hline Hepsi & 45 & 62.50 & 39 & 54.17 & & & \\
\hline Toplam & 72 & 100.00 & 72 & 100.00 & & & \\
\hline
\end{tabular}

*Khi-kare testine göre gruplar arasındaki fark $p>0.05$ için anlamsızdır.

\section{İşletmelerin tarım sigortasına ait genel bilgileri}

Araştırmanın bu bölümünde tarım sigortası yaptıran ve yaptırmayan her iki üretici grubunda tarım sigortaları ile ilgili haberdar olma ve bilgi durumları ile devlet prim desteğinden haberdar olma ve bilgi durumlarının sigorta yaptırma ve yaptırmama tercihleri üzerindeki etkileri ele alınmış ve irdelenmiştir. Üretici gruplarına öncelikle tarım sigortaları konusundan haberdar olup olmadığı sorulmuş ve tüm üreticilerin \%86.81'nin tarım sigortalarından haberdar olduğu belirlenmiştir. Üreticilerin ortalama en az 5 yıldır tarım sigortasından haberdar oldukları saptanmıştır. Yapılan Khi-kare analiz sonuçlarına göre ise sigorta yaptırma ve yaptırmama durumu ile tarım sigortalarından haberdar olma durumu arasında istatistiksel olarak fark tespit edilmiştir. Haberdar olma durumu sigorta yaptırma tercihlerini olumlu etkilemiştir (Çizelge 11).

Çizelge 11. işletmelerin tarım sigortalarından daha önceki yıllarda haberdar olma durumları Table 11. The status of enterprises to be aware of agricultural insurances in the past years

\begin{tabular}{|c|c|c|c|c|c|c|c|}
\hline \multirow{2}{*}{$\begin{array}{c}\text { Tarım } \\
\text { sigortalarından } \\
\text { haberdar }\end{array}$} & \multicolumn{3}{|c|}{ Sigorta durumu } & \multicolumn{4}{|c|}{ Khi-Kare } \\
\hline & $\begin{array}{l}\text { Yaptırıyor } \\
\text { (N) }\end{array}$ & $\%$ & $\begin{array}{l}\text { Yaptırmıyor } \\
\text { (N) }\end{array}$ & $\%$ & Değeri & $\mathrm{Sd}$ & $p^{*}$ \\
\hline Evet & 70 & 97.22 & 39 & 54.17 & 36274 & 1 & 0000 \\
\hline Hayır & 2 & 2.78 & 33 & 45.83 & 36.214 & 1 & 0.000 \\
\hline Toplam & 72 & 100.00 & 72 & 100.00 & & & \\
\hline
\end{tabular}

*Khi-kare testine göre gruplar arasındaki fark $\mathrm{p}<0.05$ için anlamlıdır.

Tarım sigortaları kapsamında daha sonra her iki üretici grubuna tarım sigortaları konusunda herhangi bir bilgileri olup olmadığı sorulmuş ve üreticilerin \%75.69'nun tarım sigortaları ile ilgili bilgi sahibi olduğu belirlenmiştir. Tarım sigortası yaptıran üreticilerin hepsi tarım sigorta ile ilgili yenilikleri araştırıp, ilgili kurumlara sorarak sık sık bilgi edindiklerini belirtmiştir. Yapılan Khikare analizine göre ise sigorta yaptıran ve yaptırmayan üreticilerin bilgi edinme durumları arasında istatistiksel bir fark tespit edilmiştir. Tarım sigortası hakkında bilgili olan üreticilerin sigorta yaptırma tercihlerinin olumlu olduğu görülmüştür (Çizelge 12). 
Çizelge 12. işletmelerin tarım sigortası ile ilgili bilgi sahibi olma durumu Table 12. Information status of enterprises about agricultural insurance

\begin{tabular}{lccccccc}
\hline \multirow{2}{*}{$\begin{array}{c}\text { Tarım sigortası } \\
\text { bilgi }\end{array}$} & \multicolumn{3}{c}{ Sigorta Durumu } & \multicolumn{5}{c}{ Khi-Kare } \\
\cline { 2 - 8 } & $(\mathrm{N})$ & $\%$ & $\begin{array}{c}\text { Yaptırmıyor } \\
(\mathrm{N})\end{array}$ & $\%$ & Değeri & Sd & \multirow{2}{*}{$\mathrm{p}^{*}$} \\
\hline Bilgisi var & 72 & 100.00 & 53 & 73.61 & \multirow{2}{*}{21.888} & \multirow{2}{*}{1} & \multirow{2}{*}{0.000} \\
Bilgisi yok & 0 & 0.00 & 19 & 26.39 & & \\
\hline Toplam & 72 & 100.00 & 72 & 100.00 & & \\
\hline
\end{tabular}

*Khi-kare testine göre gruplar arasındaki fark $p<0.05$ için anlamlıdır

Araştırma alanındaki tarım işletmelerinin tarım ile ilgili yenilikleri nerelerden takip ettikleri ve tarımsal faaliyetlere katılım düzeyleri ortaya konulmuştur. Ayrıca üreticilerin kitle iletişim araçları ile olan ilişkileri de saptanmıştır. Ürün sigortası yaptıran üreticilerin \%36.11'inin sigorta hakkındaki bilgi kaynağı sigorta şirketleri iken ürün sigortası yaptırmayan üreticilerin \%27.78'inin ise Tarım Ill ve Illçe Müdürlükleri ve televizyon ile internet olduğu tespit edilmiştir. Üreticilerin sigorta prim desteğinden haberdar olma durumları incelendiğinde; \%70.14'nün sigorta prim desteğinden haberdar olduğu, \%29.86'sının ise sigorta prim desteğinden haberdar olmadığı sonucuna ulaşılmıştır.
Üreticilerin sigorta prim desteğinden \%30.56'sının etkilendiği, \%69.44'nün ise sigorta prim desteğinden etkilenmedikleri sonucuna ulaşılmıştır. Sigorta yaptırmayan üreticilerin \%43.06'sının devlet prim desteğinden etkilendikleri saptanmıştır. Fakat devlet desteğinin kendileri için yeterli olmadığını ve gelirlerinin yetersiz olduğunu belirtmişlerdir. Sigorta yaptıran üreticilerin ise sigorta prim desteğinden etkilenmediği halde ürünlerini sigorta yaptırmayı tercih etmenin daha yararlı olacağı sonucuna ulaşılmıştır (Çizelge 13).

Çizelge 13. işletmelerin tarım sigortası prim desteğine olan tutumları

Table 13. Enterprises' attitudes towards agricultural insurance support

\begin{tabular}{lccccccc}
\hline \multirow{3}{*}{ Üretici Cevapları } & \multicolumn{3}{c}{ Sigorta durumu } & \multicolumn{3}{c}{ Khi-Kare } \\
\cline { 2 - 8 } & $\begin{array}{c}\text { Yaptırıyor } \\
(\mathrm{N})\end{array}$ & $\%$ & $\begin{array}{c}\text { Yaptırmıyor } \\
(\mathrm{N})\end{array}$ & $\%$ & Değeri & Sd & $\mathrm{p}^{*}$ \\
\hline Etkiledi & 13 & 18.06 & 31 & 43.06 & 10.604 & 1 & 0.001 \\
\hline Etkilemedi & 59 & 81.94 & 41 & 56.94 & & \\
\hline Toplam & 72 & 100.00 & 72 & 100.00 & & \\
\hline
\end{tabular}

*Khi-kare testine göre gruplar arasındaki fark $\mathrm{p}<0.05$ için anlamlıdır

Elma işletmelerinin ürün sigortası yaptırma ve yaptırmama durumları

Araştırma bölgesinde incelenen üreticilerden, ürün sigortası yaptıranların sayısı 72'dir. Üreticilerin sigorta yaptırma nedenlerini önem derecelerine göre sıralamalarını istediğimizde birinci neden olarak "aile ekonomisini garanti altına almak" istemesi ikinci neden olarak "sürekli afet riskinin olması" ve üçüncü neden olarak "devlet desteğinin olması" olarak belirtmişlerdir (Çizelge 14). 
Çizelge 14. işletmelerin sigorta yaptırma nedenleri önem sıralaması $(1,2,3)$

Table 14. The reasons for insuring enterprises in order of importance

\begin{tabular}{lccccc}
\hline \multirow{2}{*}{ Nedenler } & \multicolumn{3}{c}{ Önem Derecesi (\%) } & Toplam & \multirow{2}{*}{$\%$} \\
\cline { 2 - 4 } (Adet) & 1 & 2 & 3 & 61 & 28.24 \\
Sürekli Afet Riskinin Olması & 76.39 & 8.33 & 0.00 & 73 & 33.8 \\
Aile ekonomisini garanti altına almak içinde & 9.72 & 29.17 & 62.5 & 73 \\
Kredi çekerken zorunlu olduğu için & 6.94 & 5.56 & 11.11 & 17 & 7.87 \\
Modern tarımın gerekliliği olduğu için & 0.00 & 4.17 & 1.39 & 4 & 1.85 \\
Devlet desteğinin olması & 6.94 & 51.39 & 23.61 & 59 & 27.31 \\
Sigorta yaptıranların kazanımlarını görmem & 0.00 & 1.39 & 1.39 & 2 & 0.93 \\
\hline TOPLAM & 100.00 & 100.00 & 100.00 & 216 & 100.00 \\
\hline
\end{tabular}

Tarım sigortası yaptıran üreticilerin $\% 73.61$ 'i ile çoğunluğunun 1-4 yıldır elma bahçelerini tarım sigortası yaptırdığı belirlenmiştir. İşletmelerde 5 yıldan daha uzun süredir tarım sigortası yaptıran üreticilerin oranı ise \%26.39'dur. Sigorta yaptıran üreticilerin \%33.33'ü kooperatiflerden, \%25.00' sigorta şirketlerinden ve $\% 41.66^{\prime}$ sı ise diğer sigorta yapan kuruluşlardan sigorta yaptırdığı tespit edilmiştir. Ortalama ise yaklaşık 35 dekar alanın sigorta ettirildiği belirlenmiştir. Üreticiler tarafından 2017 yılında ortalama 6762TL prim ücreti ödenmiş ve ortalama 5620TL sigorta bedeli alındığı saptanmıştır.

Ürün sigortası yaptırmayan üreticilere, sigorta yaptırmama nedenleri sorulduğunda önemlilik derecesine göre "sigorta primlerinin yüksek olması", "gelir yetersizliği ve düzensizliği" ve "sigorta şirketlerine güvenmediklerini" belirtmişlerdir (Çizelge 15).

Çizelge 15. işletmelerin ürün sigortası yaptırmama nedenleri önem sıralaması $(1,2,3)$

Table 15. The reasons for enterprises not to take out insurances in order of importance

\begin{tabular}{lccccc}
\hline \multirow{2}{*}{ Nedenler } & \multicolumn{3}{c}{ Önem derecesi (\%) } & Toplam & \multirow{2}{*}{ (Adet) } \\
\cline { 2 - 5 } & 1 & 2 & 3 & & 8.33 \\
\hline Çevremde olumsuz örnekler var & 20.83 & 4.17 & 0.00 & 18 & 8.31 \\
Sigorta şirketlerine güvenmediğim için & 29.17 & 23.61 & 18.06 & 51 & 23.61 \\
Sigorta primlerinin yüksek olması & 26.39 & 30.56 & 19.44 & 55 & 25.46 \\
Tarım sigortası hakkında yeterli bilgim yok & 12.5 & 6.94 & 9.72 & 21 & 9.72 \\
Zarar bedelinin ödeneceğine inanmıyorum & 4.17 & 6.94 & 11.11 & 16 & 7.41 \\
Çok fazla evrak işi gerektirdiğinden & 0.00 & 2.78 & 8.33 & 8 & 3.7 \\
Nerede nasıl yaptıracağımı bilmiyorum & 0.00 & 6.94 & 0.00 & 5 & 2.31 \\
Gelir yetersizliği ve düzensizliği & 6.94 & 18.06 & 33.33 & 42 & 19.44 \\
\hline TOPLAM & 100.00 & 100.00 & 100.00 & 216 & 100.00 \\
\hline
\end{tabular}

Tarım sigortası yaptırmayan üreticilerin nedenleri ile ilgili tarım arazilerinin küçük, parçalı ve dağınık, üreticilerin gelir seviyesinin ve eğitim düzeyinin düşük, doğal risklere karşı kaderci olması gibi nedenlerden dolayı tarım sigortasının üreticiler arasında yeterince yayılmadığı ve tercih edilmediği tespit edilmiştir. Belirtilen nedenler incelendiğinde tarım sigortaları konusunda üreticilerin önyargılı olduğu bu konuda bilgilendirme ve yayım çalışmalarına intiyaç duyulduğu anlaşılmaktadır.

Görüşülen üreticilere 'Hangi Durumlar sağlanırsa sigorta yaptırırsınız?' sorusu sorulduğunda ise sigorta yaptırmayanların istenilen şartların sağlanması durumunda sigorta yaptırmaya karar verecekleri sonucuna ulaşılmıştır. Görüşülen üreticilerin $\% 27.78^{\prime} i$ primler düşerse, $23.61^{\prime} \mathrm{i}$ sigorta şirketlerine güvenleri artarsa ürün sigortası yaptıracakları belirtilmiştir.

Sonuç olarak, tarım sigortaları uygulamalarında üreticilerin sosyo-demografik özelliklerinin sigorta yaptırma ve yaptırmama tercihlerinde payı önemlidir. Yaş ortalaması 45 yaş ve altında olan genç üreticiler ve eğitim düzeyi yüksek olan üreticilerin tanıtım toplantılarına, tarım sigortaları kapsam ve şartlarını öğrenmeye daha ilgili oldukları ve sigorta yaptırma konusunda kararlı oldukları gözlemlenmiştir. Genel olarak sigorta yaptırma konusunda kararsızlık yaşayan üreticilerin, yenilikleri, fırsatları ve teknolojiyi yakından takip etmedikleri belirlenmiştir. Sigorta yaptıran 
üreticilerde gelir düzeyinin yüksek olduğu, üretimde mali kayıp yaşamak istemedikleri ve sahip oldukları arazilerin daha geniş olduğu anlaşılmıştır. Sigorta yaptırmayan üreticilerin üretimde hisseli, ortak, kira, parçalı ve küçük arazi kullandıkları tespit edilmiştir. illçede son yıllarda yaşanan don ve dolu olayları arazisi büyük olan üreticileri sigorta yaptırmaya karar vermede olumlu etkilemiştir. Üreticilerin doğal koşullara karşı ürünlerini ve aile ekonomilerini korumak istedikleri belirlenmiştir. Sigorta yaptırmayan üreticilerin ise genellikle arazilerinin parçalı, kira veya ortak olmasından dolayı sigorta yaptırmaya intiyaç duymadıkları tespit edilmiştir. Sigorta yaptırmayan üreticilerin çoğunluğunun Çiftçi Kayıt Sistemine güncel olarak kayıtlı olmadıkları belirlenmiştir. Bu durum sigorta yaptırmalarını engelleyici bir başka faktör olmuştur. Tarım sigortalarına verilen prim desteği de tarım sigortası yaptırmaya karar vermede etkili olan değişkendir. Üreticilerin \%70.14'ü prim desteğinden haberdar ve \%29.86'sı prim desteğinden haberdar olmadığı belirlenmiştir. Üreticilere göre tarım sigortasının yaygınlaşmamasının önemli nedenleri gelir yetersizliği ve sigorta alışkanlı̆̆ının kazanılmamış olmasıdır. Çiftçiler sigorta konusunda yeterli bilgiye sahip olmadıklarını, sigorta şirketlerine güvenmediklerini, sigorta primlerinin yüksek ve sigorta bedellerinin düşük olduğunu belirtmişlerdir. Öncelikle sigorta konusunda üreticilerin güvenleri sağlanmalı ve üreticilere bu konuda kanuni teminat verilmelidir. Sonrasında sigorta bilincinin oluşması için çiftçilerle danışmanlar aracılığı ile birebir iletişime geçilmesine intiyaç vardır. Tarım sigortaları konusunda bilgisi olan üreticiler tarım sigortasına daha sıcak bakmaktadır. Eğitim düzeyleri yükseldikçe sigortaya olan ihtiyaçları artmaktadır. Genç üreticiler sigorta yaptırmanın kazanımlarını gördükçe sigorta ile ilgili duyuruları sık sık takip etmekte ve tarım ile ilgili bilgilendirme toplantılarına daha fazla ilgi duymaktadır. Bu dikkate alınarak istekli çiftçilere destek olunabilir ve sigortaya katılımları artırılabilir.

\section{ÖZET}

Amaç: Bu çalışmada; Denizli ili Çivril ilçesinde elma yetiştiriciliği yapan işletmelerin tarım sigortası yaptırma ve yaptırmama tercihlerini etkileyen faktörlerin belirlenmesi amaçlanmıştır.

Yöntemler ve Bulgular: Elma üretiminin yoğun olarak yapıldığı ilçede, tarımda sigorta uygulamaları da yaygın olarak yapılmaktadır. Dolayısıyla, elma yetiştiriciliğinde tarım sigortası yaptıran üreticiler ve yaptırmayan üreticiler araştırmanın ana kitlesini oluşturmuştur.
Oransal yöntem kullanılarak elma üretiminde sigorta yaptıran (72), sigorta yaptırmayan (72) toplam 144 üretici ile yüz yüze anket yöntemiyle görüşme yapılmıştır. Veriler 2016-2017 üretim dönemini kapsamaktadır. Sigorta yaptıran ve yaptırmayan işletmelerin sosyo-demografik özellikleri irdelenmiştir. Araştırma sonuçlarına göre; toplam üreticilerin \%86.81'nin tarım sigortasından ortalama 5 yıldır haberdar olduğu belirlenmiştir. Üreticilerin \%75.69'nun tarım sigortaları ile ilgili bilgileri Tarım ve Orman i̇lçe Müdürlüğü, sigorta şirketleri, televizyon ve internet kaynaklarından sağladığı saptanmıştır.

Genel Yorum: İşletmelerin \%69.44'ünün devletin sigorta prim desteği uygulamasından olumlu etkilendiği saptanmıştır. Üreticilerin \%30.56'sının ise sigorta prim desteğinden etkilenmedikleri sonucuna ulaşılmıştır. 2017 üretim sezonu için sigorta yaptıran işletmelerin elma dikili alanları ortalaması 35 dekardır. Ayrıca sigorta yaptıran üreticilerin ortalamada 6762 TL prim ücreti ödediği saptanmıştır. Sigorta yaptıran üreticilerin yaş ortalamalarının küçük, eğitim seviyelerinin yüksek ve arazilerinin olması sigorta tercihlerini olumlu etkilemiştir. Sigorta yaptırmayan üreticilerin ise yaş ortalamalarının büyük, eğitim seviyelerinin düşük ve arazilerinin küçük, parçalı olması sigorta tercihlerini olumsuz etkilemiştir.

Çalışmanın Önemi ve Etkisi: Denizli ili Çivril ilçesinde elma üretimini tehdit eden riskler ve bu risklere karşı üreticilerin tutumları, üreticilerin sosyo-demografik özellikleri ve sigorta yaptırma/yaptırmama tercihlerinin incelenmesi.

Anahtar Kelimeler: Çivril, elma üreticileri, sosyo demografik özellikler, tarım sigortası.

\section{TEŞEKKÜR}

Bu çalışma, Süleyman Demirel Üniversitesi, Fen Bilimleri Enstitüsü, Tarım Ekonomisi Ana Bilim Dalı’nda hazırlanan Yüksek Lisans tezinin bir bölümüdür. Yüksek lisans tez çalışmamızı 5002-YL1-17 Nolu Proje kodu ile destekleyen Süleyman Demirel Üniversitesi Bilimsel Araştırma Projeleri Yönetim Birimi Başkanlığına teşekkür ederiz.

\section{Çıkar çatışma beyanı}

Yazar(lar) çalışma konusunda çıkar çatışmasının olmadığı beyan eder.

\section{Kaynaklar}

Akçaöz H, Özkan B, Kızılay H (2006) Antalya ilinde tarımsal üretimde risk yönetimi ve tarım sigortası 
uygulamaları. Tekirdağ Ziraat Fakültesi Dergisi 3(2): 93-103.

Akdemir Ş, Binici T, Şengül H, Akçaöz H, Karlı B, Aktaş E, Gizer M (2001) Bölge Bazlı Tarım Sigortasının (Area Based Index Insurance) Türkiye'de Seçilmiş Bölgeler İçin Potansiyel Sigorta Talebinin ve Talebin Karşılanabilirliğinin Belirlenmesi. T. C. Tarım ve Köyişleri Bakanlığı; Tarımsal Ekonomisi Araştırma Enstitüsü (TEAE), Yayın No: 60, Ankara.

Anonymous (2019) TUiK, 2019. Türkiye istatistik Kurumu Devlet Destekli Tarım Sigortaları. http://www.TÜİK.gov.tr. (Erişim Tarihi: 12.06.2019)

Arshad M, Amjath-Babu TS, Kächele H, Müller K (2015) What drives the willingness to pay for crop insurance against extreme weather events (flood and drought) in Pakistan? A hypothetical market approach. Climate and Development 8(3): 234-244.

Binici T, Koç AA, Zulauf CR, Bayaner A, (2003) Risk Attitudes of Farmers in Terms of Risk Aversion: A Case Study of Lower Seyhan PlainFarmers in Adana Province, Turkey. Turkish Journal of Agriculture\&Forestry 27(5): 305-312.

Boz i (1993) Tarım Sigortasının Polatlı İlçesinde Yayılması ve Benimsenmesi Üzerine Bir Araştırma. Ankara Üniversitesi, Ziraat Fakültesi, Yüksek Lisans Tezi, Ankara.

Ceyhan V, Cinemre HA, Demiryürek K (1996) Samsun ili Terme ilçesinde çiftçilerin risk davranışlarının belirlenmesi. Türkiye 2. Tarım Ekonomisi Kongresi 46 Eylül, Adana.

Çetin B, (2007) Tarım Sigortaları, Nobel Basımevi, 256s, Ankara.

Çukur F, Saner G, Çukur T, Uçar K (2008) Malatya ilinde kayısı üreticilerinin riskin transferinde tarım sigortasına bakış açılarının değerlendirilmesi: Doğanşehir îlçesi Polatdere Köyü Örneği. Ege Üniv. Ziraat Fak. Derg. 45(2): 103-111.

Farzaneh M, Allahyari MS, Damalas CA, Seidavi A (2017) Croplnsurance as a Risk Management Tool in Agriculture: The Case of Silk Farmer in Nothern Iran. Land UsePolicy 64: 225-232.

Ghazanfar S, Qi Wen Z, Abdullah M, Ahmad J, Khan I (2015) Farmers' Willingness To Pay For Crop Insurance In Pakistan. Journal of Business, Economics and Finance 4(2): 166-179.

Hasdemir M, Hasdemir M, Gül U, Yasan Ataseven Z (2014) Türkiye'de Jeotermal Seracılığın Mevcut Durumu İle Karar Verme Süreçlerinde Etkili Olan Faktörlerin Analizi. TEPGE YAYIN NO: 227, ISBN: 978-605-4672-60-8.
İkikat Tümer E, (2011) Bitkisel Ürün Sigortası Yaptırma İsteğinin Belirlenmesi: Tokat illi Örneği. Atatürk Üniversitesi Ziraat Fakültesi Dergisi 42(2): 153-157.

İkikat Tümer E, Burak, HB, Uslu Z (2019) Çiftçilerin Tarım Sigortası Yaptırma İstekliliği: Konya ili Ilgın ilç̧esi Örneği. KSÜ Tarım ve Doğa Dergisi 22(4): 571576.

Kabaoğlu H, Birinci A, (2019) Comparative Analysis of Hazelnut Farming Enterprises' Approach to Agricultural Insurance: Case Study of Duzce Province. International Journal of Scientific and Technological Research Vol.5, No.4.

Keskinkılınç K, (2013) Tarım Sigortacılığı: Dünya ve Türkiye'deki Uygulamaların Değerlendirilmesi. Çukurova Üniversitesi, Fen Bilimleri Enstitüsü, Yüksek lisans Tezi, 107s. Adana.

Kiracı MA, Kıran T, Solak E, Doğu K, Altıntaş A (2014) Trakya'da Yer Alan Bağcilık İşletmelerinde Ürün Sigortası Uygulamalarına Yönelik Üreticilerin Yaklaşımları, Karşılaşılan Sorunlar ve Çözüm Önerileri. Trakya University Journal of Natural Sciences 15(1).

Kızıloğlu R, (2017) Üreticilerin Tarım Sigortası Yaptırmaya Etkileyen Faktörlerin Belirlenmesi Konya ili Akşehir illçesi Örneği. Alınteri Journal of Agricultural Sciences 32(1): 19-26.

Pezikoğlu F, Ergun ME, Öztürk $M$, Altıntaş $A$, Uçar $M$ (2012) Bursa ilinde bitkisel ürün sigortası uygulamalarına yönelik çiftçi yaklaşımı. 10. Ulusal Tarım Ekonomisi Kongresi, 1098-1102, 5-7 Eylül, Konya.

Sayın B, Çelikyurt MA, Kaya N (2014) Üretici Gözüyle Tarım Sigortaları Uygulamaları: Antalya İli Örneği. XI. Tarım Ekonomisi Kongresi, 3-5 Eylül 2014, cilt 2: 1077-1084 Samsun.

Sevim U (2010) Türkiye'de Tarım Sigortalarında Tarım Sigortaları Havuzu ve Tarsim Uygulaması. Karadeniz Teknik Üniversitesi, Sosyal Bilimler Enstitüsü, Yüksek Lisans Tezi, 171s, Trabzon.

Uralcan Ş (2005) Sigortacılık Uygulamaları, Anadolu Üniversitesi Basımevi, 220s, Eskişehir.

Tekin A, Karlı B, Gül M, (2017) Development of implementation of agricultural insurance in Turkey. Scientific Papers-Series Management Economic Engineering in Agriculture and Rural Development 17(2): 355-364.

Terin M, Aksoy A (2015) Devlet Destekli Bitkisel Ürün Sigortası Uygulama Sonuçları Üzerine Bir Araştırma: Ortadoğu Anadolu (TRB) Bölgesi Örneği. ÇOMÜ Zir. Fak. Derg. 3(2): 35-43.

Yavuz, G. (2010) Polatı ı ilçesinde üreticilerin tarım sigortası yaptırmaya karar verme sürecinde etkili 
olan faktörlerin analizi, Tarımsal Ekonomi Araştırma Enstitüsü, Yayın No:188, s.39, Ankara. 